\title{
The Development of Sparkol Videoscribe Based Internet Learning Media in Improving Writing Skills of Indonesian Language for Elementary School Students
}

\author{
Ana Sofiya, Bambang Yulianto \& Hendratno \\ Universitas Negeri Surabaya \\ Surabaya, Indonesia \\ anasofiya1974@gmail.com
}

\begin{abstract}
The key to the success of learning is the credibility of a teacher in the classroom when utilizing and mediating in addition to curriculum's greatness or the full range of school facilities and circumstances. Teachers have responsibilities and duties in planning and practicing the plan in the learning process.

Sparkol video scribe-based learning media aims to facilitate students to understand the material that requires sound clarity, easiness in noting, and easiness of use. This can assist the implementation of learning activities.

The development of a good learning media should be in accordance with the requirements proposed by Nieven (1999: 127) including (1) validity; (2) practicality; (3) and effectiveness. Validity of teaching materials are determined by some indicators including (a) the strength of the theory that exists in the component of teaching materials/content validity; (b) all components of instructional materials/construct validity shall be internally consistent. Positive criteria of practicality include (1) teachers; and (2) students. Effectiveness indicators include (a) the existence of student interest in the learning program; (b) a positive impact on the achievement of learning outcomes. Criteria of effectiveness are (a) the level of students' activeness based on observation; (b) the level of students' activity based on responses; (c) completeness level of student learning outcomes.

After testing and validating the learning media are conducted, feasible use are developed. Classically there is a significant increase in pretest and post-test results. 92\% students completed the study, the average grade value reached 87.56.
\end{abstract}

Keywords-Inquiry Learning, Environment, Student Activities, Critical Thinking Skills.

\section{INTRODUCTION}

Writing is an expressive and productive activity. According to Byne [1] writing is a skill of using the most complex language compared to the other skill. Consequently, many students felt hard to express their ideas in writing form.
(Yulianto:2009) stated an old paradigm that put the teacher as the center of learning and the students as the object of the learning. However, this paradigm cannot be used in the innovative Indonesian language learning. The new paradigm that is used in an innovative learning is student-centered learning model which put the students as the subject of learning. This paradigm builds the students understanding actively through a set of experiences to create new experiences. It also let the students, as the subject in the teaching and learning activity, hold the control of the learning, while the teacher has role to be a facilitator and motivator in supporting and assisting the students in doing the learning.

Through information and technology development, particularly multimedia based, in nowadays, teacher can help their students in supporting their learning. According to Zeembry in [3] multimedia is a combination between text, audio, video, animation, picture, and interactive. Learning using multimedia product can be used independently without having any guidance from the others that will help the students in facing their learning easier with complete contents. [3] the development of a good learning media should be in accordance with the requirements proposed by [4] including (1) validity; (2) practicality; (3) and effectiveness. Validity of teaching materials are determined by some indicators including (a) the strength of the theory that exists in the component of teaching materials/content validity; (b) all components of instructional materials/construct validity shall be internally consistent. Positive criteria of practicality include (1) teachers; and (2) students. Effectiveness indicators include (a) the existence of student interest in the learning program; (b) a positive impact on the achievement of learning outcomes. Criteria of effectiveness are (a) the level of students' activeness based on observation; (b) the level of students' activity based on responses; (c) completeness level of student learning outcomes. 


\section{PREVIOUS STUDIES}

There were several previous studies which has relevancy with this study.

The first previous study was taken by Noviardani Kartika Prameswari. Which had concern about the implementation of computer with animation development in inquiry learning under the topic my neighborhood environment.

The other previous study was taken by Nur Izatil Hasanah in 2014. The study took focus on the development of Sing Show Guess games by using flashcard to introduce English vocabulary to group A kindergarten.

Based on those previous studies, they showed that the implementation of computer-based media will contribute to the students' learning outcomes.

\section{Writing Concept}

[5] proposed that the linguistic learning process should be in accordance with the principles of language learning process in general. the principles should focus on the speaking learning activity not only about the language. There are several matters that need the teacher's attention in implementing Indonesian learning in the class, such as; (1) Indonesian language learning process should be directed to train the students' linguistic ability in real condition, and give more portion to the active skill (speaking and writing) and receptive skill (reading and observing). (2) students are able to correct the other students' mistakes.

Writer should have the ability to express ideas in writing form, and understand the language structure and vocabularies. Thus, expressing ideas activity is a productive and expressive activity [6]

The benefits of writing in Indonesian language learning process are (1) mastering the ability to remember a text in writing or verbal form; (2) comprehending many knowledge (for instance, writing the main ideas from various books to elevate students' understanding); (3) elevating the students' skill to develop their knowledge, art, and technology; (4) spreading the use of a good and correct Indonesian language (using a formal and standard Indonesian language in writing) in many circumstances, and (5) relating Indonesian language lesson to the other science.

\section{METHOD}

This study used research and development (R\&D) method. It is a kind of research method that is used to test the effectiveness of a product [7] The development that had been done by the researcher was the development of Indonesian language learning media development using sparcol videozine based to elevate the sixth grade students writing ability. This media would be tested and developed.
This study used learning media development of Four-D Model. according to [8] there are four steps of the development model, such as; defining, designing, developing, and disseminating. In this study, the researcher simplified the step without using the disseminating step. Thus, the media would be used only in the school where the researcher took the study.

The study consisted of defining step which contained of analyzing the problem, students, lesson material, concept, and the learning purpose. Then planning steps contained of media planning and the expert's validation.

Developing step was the step to produce the product. The development had been done in two steps, such as (1) expert appraisal that is followed by having revision; and (2) development testing.

The data analysis technique that was used was media validity analysis, students' activity observation analysis, teacher activity observation analysis, and students' learning outcomes analysis.

The data analysis instruments in the media development process were media validation checklist and fieldnote. In the media development quality was media validation checklist, and it was also used in the implementation of learning media development.

The following is the students' critical thinking skill result on every cycle based on indicator achievement.

\section{RESULT AND DISCUSSION}

In defining step on May 2018 [3] there were four steps that had been done. firstly, the researcher's problem analysis got score 3 which was good. Secondly, students' analysis got score 4 which was very good. Thirdly, the researcher' concept analysis got score 3 which was good. Lastly, learning purpose analysis got score 4 which was very good.

In the designing step, there were 3 steps. They were media planning got score 3 which was good, media implementation got score 4 which was very good, the researcher validation got score 4 which was very good.

In developing step, there were 2 steps, such as; expert appraisal got score 4 which was very good, and developmental testing got score 4 which was very good. Media development steps see appendix.

in learning media development, the results started from defining steps until the researcher development got score 4 which was very good in 6 aspects, while the researcher got score 3 in 3 aspects which was good. It can be concluded from the above data that the score sheet in the development of sparcol video scribe- based internet learning gave a very good validity with 91,66 percentage. Thus, the media development process was good and worth to be used. 
The content validity was done by 2 experts of primary school issue, Drs. Masengut Sukidi, M.Pd. and Mariyam Isnaini D, S.Pd., M.Pd., they were the lecturer of the primary teacher education program (PGSD) in Surabaya State University. The validators were used to validate the content inside the learning media development related to primary school basic competencies material and its relevancy to the content of learning media. There were several indicators in content instruments sheet. The researcher did twice validation to the experts. The first validation was done before the media trial test was done.

The average score of the first validator for content validity was 3.77 which meant the media can be used without any revision, as well the average score of the second validator which the score was 3.66 meant the media also can be used without any revision.

\section{A. Language validation to the Indonesia language experts}

Language validation was done by Drs. Suhartono, M.Pd the lecturer of language and art department in Surabaya State University and Maryam Isnaini D., S.Pd., M.Pd., as the Indonesian Language lecturer in primary teacher education department, both were from Surabaya State University. The researcher did twice validation to the experts. The first was done before the media trial test was done. the researcher got several inputs from the experts related to the indicator in the instrument and to the other aspects.

the average score from the first validator for the picture validation was 3.71 which meant those media can be used without need any revision. The average score from the second validator was 3.71 which mean that the media can be used without any revision.

\section{B. Media validation included picture and voice to the experts of education technology.}

Media validation was done by ghe experts of media, Prof. Dr. Mustaji, M.Pd and Dr. Fajar Arianto, S.Pd., M.Pd., the lecturer of education technology department in Surabaya State University. The researcher did twice validation to the experts. The first validation was done before the media trial test was done from the validator, the researcher got several inputs related to the aspects in the instruments.

The average score of first validator was 3,88 for the voice validation which meant the media can be used without any revision. meanwhile, the average score of the second validator got score 4 which meant the media can be used without any revision.

The scoring from the first validator got average score 3.71 for the picture validation which meant the media can be used without any revision. Meanwhile, the second validator gave the average score 3.71 for language validation which meant the media can be used without any revision.

\footnotetext{
C. The result of observation students' activities to the implementation of the developed media.
}

The result data of students' activities to the developed media was got through the media trial test that had been done in the grade VIA SDN Wonokromo III/392 in the writing class.

The students' activities in the teaching learning activity considered to be successful when reached high score or the same with $80 \%$. Students' average score was $94,6 \%$, the percentage was higher from the indicator. Thus, it concluded that that the students were very active in following the class using the developed media.

D. The teacher activity observation result to the implementation of the developed media.

The data of the teacher activity observation result to the developed media were gathered from the media trial test activity that was done in grade VIA SDN Wonokromo III/392 in the writing class.

The teacher activity in the teaching learning activity considered to be successful when $76 \%$ until $99 \%$ of the lesson material can be acquired by the students. from the observation data, it showed $93.75 \%$ of the lesson material had been acquired well by the students.

\section{E. Students responses to the implementation of sparcol video scribe- based internet learning.}

From the data of student's responses go the developed media to the students of grade VIA SDN Wonokromo III/392 Surabaya in the writing class. It showed that not all of the students in the class involved in the trial test process. There were only 20 from 34 students that had been chosen randomly to follow the trial test.

The percentage result of the student's responses was $100 \%$ the students were happy with the developed media so it could get a positive response from the students.

\section{F. Teacher's response to the implementation of sparcol video scribe- based internet learning.}

The data of teacher's response to the developed media was gathered from media trial test that had been done to the students of grade VIA SDN Wonokromo III/392 Surabaya in writing class. There were 2 teachers that was pointed as the observer for the trial test of the developed media

The result of the teacher's response was $94.6 \%$. Thus, the developed media got positive response from the teacher.

G. The students outcomes to the implementation of
sparcol video scribe-based internet learning.

There was a significant increase to the pretest and posttest. In the post test, there were only 3 students who did not passed the class. However, there were 31 students who got score higher than 75 who passed the class. The highest score of the post test was 92, while the lowest score was 72 . Classically, the level of students' successfulness after using sparcol video scribe- based internet learning can be counted through the total of the passed students 31 , divided with the total of the students 34 , times with $100 \%$ so it can be 
gathered the result of $91 \%$. While the students who did not passed can be counted through the total of the student who did not passed 3, divided with the total of the students 34 , times with $100 \%$ so it resulted $8.8 \%$ and the average score of the grade was 83.80 .

\section{CONCLUSION}

The process of the development using Four-D model consisted of four steps of developing, such as; defining (problem analysis, students' analysis, concept analysis, material analysis, writing learning purpose analysis). Planning steps (media planning and media implementation planning). Developing step (expert appraisal that was followed by revision and development testing). Resulting final result of the developed media after having revision from the experts and the data from trial test for the development.

The media quality included (1) the content validity score from the experts of primary school issue with validity score was 3.72 which meant very good; (2) voice validation by the expert of media by the expert of education technology with the validity score of 3,94 which meant very good quality; (3) picture validity by the experts of education technology with validity score was 3.71 which meant very good quality ; (4) Language validity by the experts of Indonesian language got the validity score of 3.71 which meant very good quality; (5) Students' responses got score $90 \%$ with the categorization of the students were very active; (6) Teacher's response got score $90 \%$ with the level of successfulness was very good; (7) The students' activities got score $90 \%$ with the level of successfulness was very good; (8) The result of students' outcomes in the pretest got score $72 \%$ while in the posttest got score $92 \%$ with the average score was 90 , so the level of students successfulness rise to $20 \%$.

\section{REFERENCES}

[1] S. Bailey, Academic writing: A handbook for international students. Routledge, 2014.

[2] L. Flower and J. R. Hayes, "A cognitive process theory of writing," Coll. Compos. Commun., vol. 32, no. 4, pp. 365-387, 1981.

[3] N. Ariani and D. Haryanto, "Pembelajaran Multimedia di sekolah," Jakarta: Prestasi Pustaka, 2010.

[4] N. Nieveen, "Prototyping to Reach Product Quality. Dalam Plomp, T; Nieveen, N; Gustafson, K; Branch, RM; dan van den Akker, J," Des. Approaches Tools Educ. Train., 1999.

[5] B. Yulianto, Aspek Kebahasaan dan Pembelajarannya. Unesa University Press, 2008.

[6] B. G. Nurgiyanto, "Marzuki. 2004," Stat. Ter. Yogyakarta Univ. Gajah Mada.

[7] D. Sugiyono, "Metode Penelitian Bisnis," Bandung Pus. Bhs. Depdiknas, 2008.

[8] G. E. Tompkins, Language arts: Content and teaching strategies. ERIC, 1998 